\title{
TAF7L wt Allele
}

National Cancer Institute

\section{Source}

National Cancer Institute. TAF7L wt Allele. NCI Thesaurus. Code C52610.

Human TAF7L wild-type allele is located in the vicinity of Xq22.1 and is approximately 25 $\mathrm{kb}$ in length. This allele, which encodes TAF7-like RNA polymerase II, TATA box binding protein (TBP)-associated factor, 50kDa protein, plays a role in the promotion of transcription in male germ cells. 